\title{
Study on the Fluctuation of Purchasing Power Parity
}

\author{
Hua Niu ${ }^{1}$, Xiaoyuan $\mathrm{Chu}^{2}$, Yanxin $\mathrm{Ma}^{3}$ \\ ${ }^{1}$ School of Statistics, Beijing Normal University, Beijing, China \\ ${ }^{2}$ School of Economics and Resource Management, Beijing Normal University, Beijing, China \\ ${ }^{3}$ Huhhot Central Sub-Branch, Huhhot, China \\ Email: seancxy@126.com
}

Received 6 November 2015; accepted 11 January 2016; published 14 January 2016

Copyright (C) 2016 by authors and Scientific Research Publishing Inc.

This work is licensed under the Creative Commons Attribution International License (CC BY). http://creativecommons.org/licenses/by/4.0/

c) (i) Open Access

\begin{abstract}
This paper tests the effect of per capita income, exchange rate, foreign direct investment inflows, net trade condition index and the final consumption expenditure growth rate on the fluctuation of purchasing power parity basing on panel fixed effects model during the period of 2000-2013 of 62 countries (religions). Empirical results show that the fluctuation of per capita income and exchange rate are the key factors to explain the fluctuation of purchasing power parity, however, purchasing power parity (PPP) fluctuation is influenced by the five variables has some differences in terms of magnitude and direction between different economies. The effect of the foreign investment on purchasing power parity is negative in low income economies, but other economies are the opposite, at the same time, the estimated coefficient of high income is lower than upper \& middle income economies. The growth of final consumption expenditure is helpful to improve the purchasing power parity of low income and high income economies. It is surprising that the increase in per capita income will reduce the purchasing power of some developed economies. In China, purchasing power parity will continue a growth trend in future.
\end{abstract}

\section{Keywords}

Purchasing Power Parity Exchange Rates, The Panel Model, International Comparison

\section{Introduction}

Purchasing power parity conversion factor is the number of units of a country's currency required to buy the same amounts of goods and services in the domestic market as US dollar would buy in the United States. It is an international multilateral price index calculated by the world bank using international comparison data. In the international comparison project, the World Bank has organized various countries and regions to collect thou- 
sands of specifications of the price and more than a hundred kinds of GDP expenditure basic classification data according to a unified investigation scheme, standard and time. As with other price indices, the purchasing power parity rate is considered to be the national average price, or as an explanation for the cost of living (Deaton, A., et al. 2008) [1]. As a currency conversion factor, it converts GDP and the accounting data by expenditure method into a unified monetary unit of value, which can avoid the distortion of GDP and the per capita level calculated by exchange rate method (Yu, F. D., 2015) [2]. So the world economy can be shown in a new perspective scale in term of development level and the income distribution pattern, etc. In recent years, some international organizations have used data computed in purchasing power parity (PPP) measure as the basis of relevant decisions. Such as the EU has used the GDP and per capita GDP based on purchasing power parity (PPP) measure as the basis of redistributing social structure foundation, IMF has also introduced GDP with PPP method to the calculation of the special drawing rights of the member countries, World Bank calculates the global poverty rate by purchasing power parity exchange rate (Yu, F.D., 2008 [3]; Deaton A., et al. 2014 [4]). In addition, governments can analyze the competitive advantage of their products through the PPP conversion price, and provide the basis for trade policies. Multi-National Corporation can use the data to estimate the cost of investment, return and risk, etc., which can provide a decision support for investment direction and scale. Thus, in the trend of economic globalization and regional integration process accelerating, measurement and evaluation of the world's economic and social development in the PPP exchange rate method is particularly important, and a consensus has emerged among in the international community (Fangdong Yu, 2008) [3].

Since international comparison program has set up in 1968, the United Nations and the World Bank have organized 8 rounds of international comparison. When each round of international comparison results releases, the World Bank will revise substantially the PPP extrapolating data based on the previous round at the same time. Such as Asia (excluding Japan), West Asia and Africa, the actual survey PPP data increases by $18 \%$ - 26\% than the extrapolated value (Deaton, 2014) [4]. Accordingly, Lawrence et al. (2014) calculate the global poverty population which is 1.215 billion in 2010 (ICP extrapolation based on 2005 data) and then dropped to 571 million (based on 2011 data) [5]. At the same time, the PPP data revision also makes the academic research conclusions based on the Penn world tables (Johnson, Larson, Papageorgiou and Subramanian, 2013) change. Therefore, some scholars began to question the extrapolation method. Deaton (2014) [4] pointed out it cannot expected the actually change: ICP is an international multilateral price index, and it differs from the GDP price reduction index used for inference, because the latter is compiled based on the consumer price index (CPI) and the producer price index (PPI). General speaking, specifications chosen for compiling CPI and PPI are not internationally comparable, but the specifications chosen for compiling PPP is international comparability. At the same time, the expenditure structure changes with time, especially in the rapid economic development economy, and its expenditure structure changes very quickly (Yu, F.D., 2013) [6]. If the relative inflation rate can't explain the change of PPP, then we want to know why does the purchasing power parity change or what factors affect it? It is particularly important to explore the economic factors of PPP changes in its widespread application today.

The paper proceeds as follows. In Section 2, we introduce and review the related research at home and abroad. In Section 3, we describe the data selection and variables; Section 4 then presents statistical analysis, model estimation and robustness analysis. Section 5 concludes the paper.

\section{Literature Review and Comment}

Purchasing power parity, as a kind of the multilateral price index, which is obtained by the actual investigation and extrapolation, is not only affected by extrapolation and investigation method, but also a result of the macro economic fluctuation.

Viewed from the international comparison project implementation process point, Yu, F. D (2015) pointed out that the error of statistical investigation may be the cause of the change of PPP in some areas. Since the price data collected in Africa can't present fully the local residents living costs, meanwhile, the gap between the development of Asia Pacific regions lead to a lack of specifications [2]. Deaton, A., et al. (2014) summarized the reason of the difference between the predicted value and the actual measured value in 2011 as: extrapolation data cannot capture the full variation of actual economic factors, because the purchasing power parity rate is a price index based on the international comparison [4]. And the changes in the foreign price level will affect the domestic purchasing power parity exchange rate, so the extrapolated data adjusted by the inflation rate will be different from the actual calculation data; In addition, there is a large number of standard error unrecognized between different PPP survey, for example, the purchasing power parity data of the non reference state is derived from the effect Penn, so when they become the actual survey countries in the next round of international 
comparison program, it may appear error; Finally, there are some problems in terms of representativeness and comparability. It cannot be denied that PPP fluctuation is influenced by system error of investigation and extrapolating a certain extent, however, changes in the purchasing power parity (PPP) are more relevant of economic development, economic growth and other factors.

On the one hand, scholars overseas derivate the influence factors of purchasing power parity from the relationship between relative price and per capita GDP. Gibert and Kravis (1954) found that there is a positive relationship between the purchasing power parity exchange rate and the per capita GDP converted in the nominal exchange rate, which is also called Penn effect [1]. Subsequently, Balassa and Samuelson (1964) explained effectively this phenomenon by the market competition model [7]. They assume that the more developed the countries are, the higher labor productivity in trade sectors, and the productivity of non trade department has not increased with the level of economic development. General speaking, the increase of marginal labor output in the trading sector will lead to an increase in the wage level of the Department. Under the conditions of free flow of labor elements, the wage level of non trade department will also be improved. In order to maintain profits, manufacturers are bound to increase the price of non trade goods, so the national price level will be improved overall. In the same way, the lower wages in poor countries makes the price of non trade goods relatively low, and therefore

$$
P L I=\frac{P P P}{E}=f(\text { Income })
$$

has economic theory as its support. In addition, Cheung et al. (2007) found the relative price index also shows an upward trend with the increase of per capita income in the same economy [8]. On this basis, Ravallion, M. (2010) set up a differential log model of PPP:

$$
\ln \left(P L I_{t+n i} / P L I_{t i}\right)=\alpha+\beta \ln \left(Y_{t+n i} / Y_{t i}\right)+\varepsilon_{i}
$$

( $t$ indicates year, $n$ time indicates time span, $i$ indicates countries, $Y$ indicates per GDP), the estimated results show $\beta>0$ [1]. Based on this, he proposed the dynamic Penn effect: The faster the economic growth rate is, the higher the relative price level (the ratio of the PPP to the nominal exchange rate). Combined with Froot and Rogoff (1994)'s inference: “Exchange rate changes may also affect the domestic purchasing power parity” [9], Cheung et al. (2007) expand Formula (2) to

$$
\ln \left(P P P_{t+n i} / P P P_{t i}\right)=\alpha+\beta \ln \left(Y_{t+n i} / Y_{t i}\right)+\gamma \ln \left(E_{t+n i} / E_{t i}\right)+\varepsilon_{i}
$$

and use it to explain the reasons for the changes of PPP [9]. However, whether the exchange rate impact the purchasing power parity rate or not? In order to solve this question, Robert (1994) set up a model for the United States, Canada, Germany, France, Japan, and the United Kingdom during the period of 1974-1992 using quarterly data, and results show that the exchange rate changes will affect trade products' substitution of domestic products, as a result, price level will also change [10].

On the other hand, it directly studies the relationship between a certain (some) variable and purchasing power parity. Bhagwati (1984) found that rich labor force is a factor leading to the low wages of the economy's service sector [11]; Similarly, Ravallion, M., (2014) shows that real wages will rise in the growing economies after lewis turning point, that due to lower labor affluence [12]. Clague (1985) considered that the different natural endowments would have an impact on the price level even in two economies with the same per capita GDP [13]; Robert, E. and Lipsey (2002) pointed out that the foreign investment companies are more tend to hire workers with a better education and qualifications, and pay them with a higher wages than domestic company [14]. However, wage spillover effect between different companies always pushes up the average wages level, namely foreign investment will affect the price level of the whole economy. In addition, the world bank studied the effects of a country's education level on the price level using the GDP per capita based on 1993 PPP exchange rates as a dependent variable, and per capita GDP converted in nominal exchange rate and basic education enrollment rate as independent variables (World Bank, 2008) [15].

In China, the related research is the development of foreign classical theory (model). Liu, Y. F., et al. (2007) described the price level with the increase of income using a mixed data with 88 countries for 4 years, and the results show that with the increase of the per capita income level, the relative price level index experienced a ascending trend after the first fall and then tend to stable [16]. Subsequently, Wang, L., et al. (2013) established a panel threshold model with a longer period (2000-2010) and more economies (109 countries) showing that the relative price presents a stage characteristics with the increase of per capita income, and pointed out that the "smile curve" can better describe the relationship between the two. On the other hand, it is the same with foreign 
literature, Chinese scholars also study the effect of other macroeconomic factors on the purchasing power parity [17]. Liu, Z. H., et al. (2009) found that foreign direct investment can produce a substitution effect and the trade creation effect at the same time, also produce market expansion and trade complementary effect, and thus enhanced the openness of a country's trade [18]. A direct result is to bring down the price level of developed countries and raise the level of prices in developing countries, and the world price level divergence degree is reduced. That is to say, the impact of FDI on the price level of a country depends on the level of its economic development; Sun, W. Z., (2009) explained the decline in the import price, meanwhile the increase of the export price, can lead to the increase of the actual purchasing power of money [19]. Pan, S. M., et al. (2010) confirmed that the FDI and demand factors such as government spending, trade terms and consumer preferences have a significant impact on the purchasing power of RMB, using of China's inter provincial panel model [20].

Basing on the model of Ravallion, M. (2010), this paper considers the impact of other macroeconomic factors on the purchasing power parity, and tries to provide a new way of estimating the purchasing power parity (PPP) [21].

\section{Samples and Variables}

\subsection{Sample Description}

This paper studies the impact factors of the global average price in this new period, and we choose the 62 economies' annual data during 2000-2013 period as the research object. This is mainly based on the following considerations, first of all, purchasing power parity exchange rate is equivalent to the average price of consumption, fixed capital formation and net exports. Due to consumption and net exports have obvious seasonal effect, the choice of annual data can effectively avoid the interference of seasonal factors; Secondly, the Middle East was not in the first, second, forth or fifth round of the international comparison program, and Central America and South America was not covered in the sixth round of the international comparison program (Chen. M. G, et al. 2015) [22]; Moreover, there is a big difference between the standard and the aggregation methods of the first 6 rounds of the international comparison project, so that the accuracy of the purchasing power parity data obtained a wide range of questions. Limited to the availability of some indicators, this paper finally adopts 62 economies' data during 2000-2013 period. The selected countries (Table 1) not only covers low-income developing countries, but also including the developed countries. Without special instructions, the selected data are from the World Bank.

\subsection{Variable Selection}

Exploring factors driving force for the purchasing power parity exchange rate fluctuations is the purpose of this paper, and therefore the dependent variable is purchasing power parity. We reference to Ravallion, M.,'s (2010) methods, and eventually choose the logarithmic form of first order difference of PPP exchange rates as the dependent variable [21]. While the value is greater than 0 , it indicates a rise in purchasing power parity (PPP), and the currency purchasing power in domestic declines; whereas the value is small than 0 , their currencies purchasing power in domestic rises.

According to the summary of the existing literature, this paper argues that the more important influencing factors are the economic growth rate, exchange rate, foreign direct investment and trade conditions and consumer spending. On account of dependent variable reflects annual change price, so the independent variables should be reflected as possible as the annual variation ${ }^{1}$. The specific variables setting and the descriptive statistics results are shown in Table 2 and Table 3.

Table 1. 62 economies by the world bank standard classification.

\begin{tabular}{|c|c|c|c|c|}
\hline Income Category & Low Income & Low \& Middle Income & Upper middle Income & High Income \\
\hline $\begin{array}{l}\text { Countries } \\
\text { (Regions) }\end{array}$ & $\begin{array}{l}\text { Rwanda, Uganda, } \\
\text { Mozambique, } \\
\text { Benin, etc. }\end{array}$ & $\begin{array}{l}\text { Bangladesh, Bolivia, } \\
\text { Cameroon, Guatemala, } \\
\text { Hongdu Lars, Indonesia, } \\
\text { India, Kenya, etc. }\end{array}$ & $\begin{array}{l}\text { Brazil, Botswana, } \\
\text { In China, Colombia, } \\
\text { Costa, Gabon, } \\
\text { Lebanon, Jordan etc. }\end{array}$ & $\begin{array}{l}\text { Canada, Chile, } \\
\text { Cyprus, Germany, } \\
\text { Denmark, Spain, Finland, } \\
\text { Framce, Britain, etc. }\end{array}$ \\
\hline $\begin{array}{l}\text { Aggregation } \\
\text { (ratio) }\end{array}$ & $6(9.7 \%)$ & 19 (30.6\%) & $14(22.6 \%)$ & $23(37.1 \%)$ \\
\hline
\end{tabular}

Note: According to http://data.worldbank.org.cn/country sorted.

${ }^{1}$ Secondary school enrollment rate, employment rate, the proportion of rural population and trade freedom, and other indicators are introduced to the model, unfortunately, these indicators are not pass through the significant test. 
Table 2. Sample variables and instructions.

\begin{tabular}{ccc}
\hline \multicolumn{1}{c}{ Variable } & Sign & Variable Meaning \\
\hline $\begin{array}{c}\text { Purchasing power parity } \\
\text { exchange rates }\end{array}$ & $\ln \left(P_{t} / P_{t-1}\right)$ & $\begin{array}{c}\text { The natural logarithm of purchasing power } \\
\text { parity exchange rates annual variation } \\
\text { The natural logarithm of GDP per capita } \\
\text { annual variation }\end{array}$ \\
$\begin{array}{c}\text { Economic growth rate } \\
\text { The nominal exchange rate }\end{array}$ & $\ln \left(Y_{t} / Y_{t-1}\right)$ & $\begin{array}{c}\text { The natural logarithm of nominal exchange } \\
\text { rate annual variation }\end{array}$ \\
$\begin{array}{c}\text { Foreign direct investment } \\
\text { Net trade condition index }\end{array}$ & $F D I$ & $\begin{array}{c}\text { The ratio of foreign direct investment and GDP } \\
\text { The final consumption } \\
\text { expenditure growth rate }\end{array}$ \\
\hline
\end{tabular}

Table 3. Descriptive statistics of variables.

\begin{tabular}{|c|c|c|c|c|c|c|}
\hline & $\ln \left(P_{t} / P_{t-1}\right)$ & $\ln \left(Y_{t} / Y_{t-1}\right)$ & $\ln \left(E_{t} / E_{t-1}\right)$ & FDI & $E I$ & CS \\
\hline Mean & 0.0281 & 0.0691 & 0.0068 & 4.5573 & 103.5692 & 4.3746 \\
\hline Median & 0.0167 & 0.07221 & 0.0000 & 2.8552 & 98.7336 & 3.5790 \\
\hline Maximum & 0.7000 & 0.7508 & 0.6731 & 88.0963 & 236.4172 & 396.3840 \\
\hline Minimum & -0.3730 & -0.5308 & -0.3318 & -5.6955 & 21.2181 & -293.1580 \\
\hline Standard deviation & 0.0656 & 0.1090 & 0.0866 & 6.8468 & 30.6895 & 21.5140 \\
\hline Partial degrees & 2.7664 & 0.0390 & 0.9156 & 5.1953 & 1.8386 & 8.5059 \\
\hline Kurtosis & 25.1848 & 7.1926 & 8.8181 & 45.4931 & 8.3315 & 240.0932 \\
\hline J-B Statistic & 18907.17 & 635.95 & 1345.54 & 69209.39 & 1517.09 & 2043510 \\
\hline P-value & 0.0000 & 0.0000 & 0.0000 & 0.0000 & 0.0000 & 0.0000 \\
\hline Observations & 868 & 868 & 868 & 868 & 868 & 868 \\
\hline
\end{tabular}

\section{Empirical Research}

\subsection{Statistical Characteristic}

$\ln \left(P_{t} / P_{t-1}\right)$ represents annual variation of the overall price level. In the sample period, we can see that the maximum value of the index is 0.6999 , the minimum value is -0.3730 , the average value is 0.0281 , and the median is 0.1669 from the descriptive statistical results of Table 3. The J-B statistic (18907.17) and the corresponding $P$ value ( 0 ) show that the sequence can not be considered from the same normal population. In addition, the statistical distribution of $\ln \left(P_{t} / P_{t-1}\right)$ is shown (Figure 1 ) that the data are mostly concentrated in the range of $-0.05-0.1$, and the right side of the mean value is more than the left side, which also shows the non normality trait of the index data. The statistics characteristic of $\ln \left(P_{t} / P_{t-1}\right)$ shows that the world's average price level is rising, that is consistent with the intuition of residents in most countries, but the purchasing power of the economy has different characteristics at different stages of development.

The descriptive statistical results of Table 4 shows that the low and middle-income economies experiences a largest change in term of purchasing power parity, and the mean value is 0.0461 . Followed by upper \& middle income and low-income economies, and the mean value are 0.0395 and 0.0332 respectively. The mean value of these economies are higher than the average level in all samples (0.0281); however, mean value of high-income economies is minimum (0.005). There is not any change of the above order taking median in count. Furthermore, Figures 2(a)-(d) shows PPP exchange rate changes distribution of four types economies respectively. That is $86 \%$ of the high income economy concentrates in the range of $-0.5-0.5$, but other economies are different, because of most data concentrates in the range of $-0.25-0.75$. We can concluded that with the increase of income level, the average annual change in purchasing power parity presents a characteristic of first increase and then decrease. 
Table 4. The statistic comparison between economies.

\begin{tabular}{ccccc}
\hline Income Category & Mean & Median & Standard deviation & Observations \\
\hline Low Income & 0.0332 & 0.0254 & 0.0584 & 0.0733 \\
Low \& middle Income & 0.0461 & 0.0346 & 0.0625 & 0.0541 \\
Upper middle Income & 0.0395 & 0.0307 & 0.0656 \\
High Income & 0.0054 & 0.0167 & 0.065 \\
All the samples & 0.0281 & & 868 \\
\hline
\end{tabular}

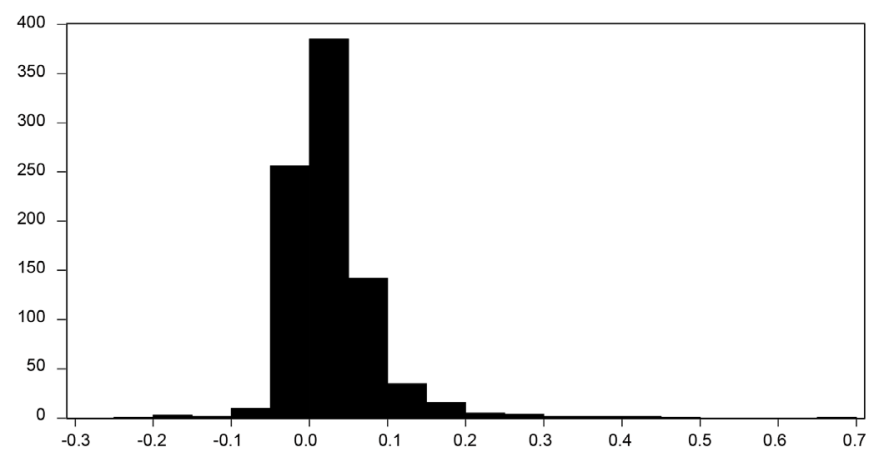

Figure 1. $\ln \left(P_{t} / P_{t-1}\right)$ distribution.

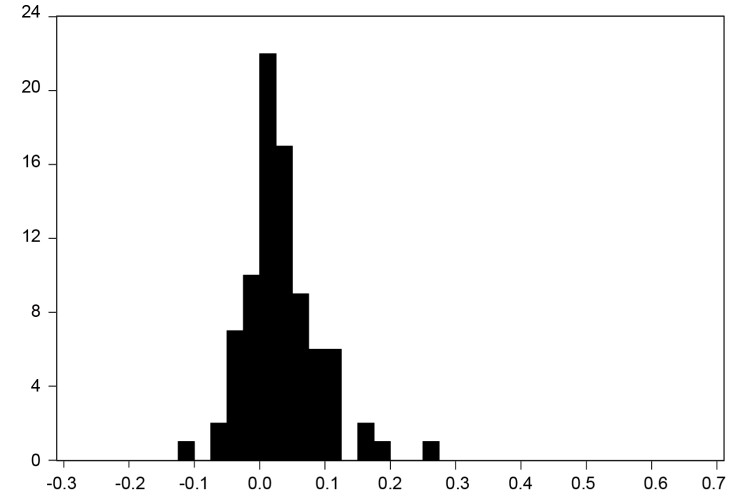

(a)

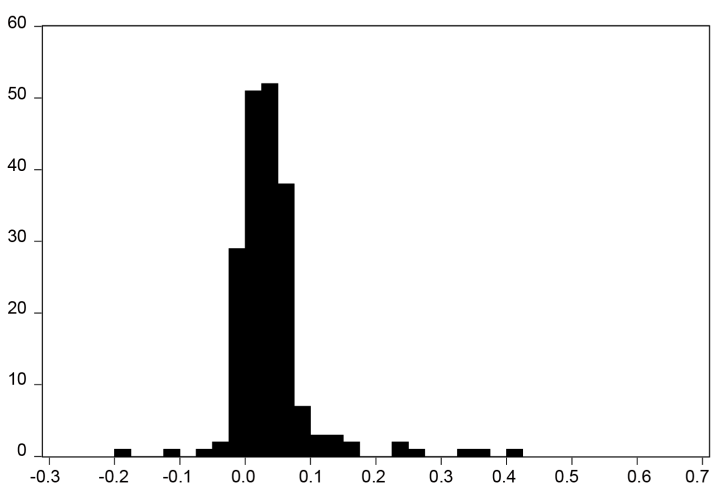

(c)

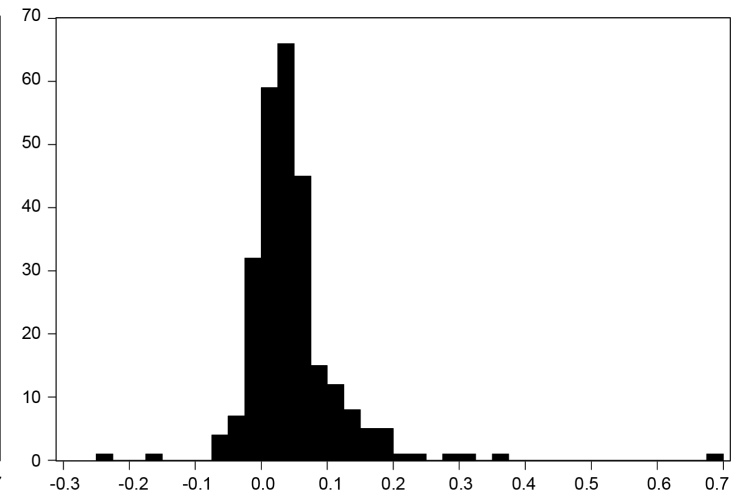

(b)

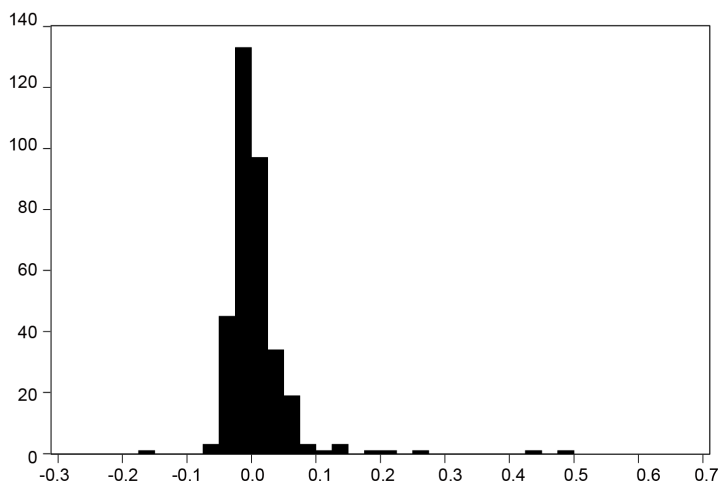

(d)

Figure 2. (a) $\ln \left(P_{t} / P_{t-1}\right)$ distribution in low-income economies. (b) $\ln \left(P_{t} / P_{t-1}\right)$ distribution in low and middle income economies. (c) $\ln \left(P_{t} / P_{t-1}\right)$ distribution in upper middle income high-income economies. (d) $\ln \left(P_{t} / P_{t-1}\right)$ distribution in economies. 


\subsection{Panel Model Estimation}

The data selected in this paper have 3D information, that is the cross section, time and variable. Data Panel model can be used to construct and test a more real behavior equation for deep analysis than only using cross section data or time series data (Tie mei Gao, 2009) [23]. Therefore, this study chooses a Panel Data model as the analytical tool. If the model set form is not correct, the estimation results will deviate from the economic reality, so it is important to set up the model. We compute $F_{2}=4.8694>F_{2}[366,496]=1.1728$ and $F_{1}=4.9344>F_{1}[305,496]=1.1823$ using the form setting test method ${ }^{2}(k=5, T=14, N=62)$, and it indicts rejecting $\mathrm{H}_{2}$ and $\mathrm{H}_{1}$, so we should adopt variable coefficient model. In addition, Hausman Test statistics $W=$ 27.6155, $P=0.0001<0.05$, which rejects the null hypothesis. Based on the two test above, the model is set to a fixed effect variable coefficient model. The specific form is as follows:

$$
\begin{aligned}
\ln \left(P_{i t} / P_{i t-1}\right)= & \alpha+\alpha_{i}+\beta_{1 i} \ln \left(Y_{i t} / Y_{i t-1}\right)+\beta_{2 i} \ln \left(E_{i t} / E_{i t-1}\right)+\beta_{3 i} F D I_{i t}+\beta_{4 i} E I_{i t} \\
& +\beta_{5 i} C S_{i t}+\varepsilon_{i t} \quad i=1,2, \cdots, 62, \quad T=1,2, \cdots, 14
\end{aligned}
$$

where $\alpha_{j}$ is fixed effects of different degree in the co-integration relationship of various units, $\beta_{j i}(j=1,2, \cdots, 5)$ is co-integration coefficient of $j$ across each section, and $\varepsilon_{i t}$ random error term.

\subsubsection{Panel Unit Root Test}

Whether there is a long-term co-integration relationship between the dependent variable and independent variable or not, it depends on integration of each variable [23]. At present, the unit root test of panel co-integration have not obtained the consistent conclusion, so this article selects 5 kinds of unit root test method: LLC test (Levin-Lin-Chu), Breitung test, Im-Pesaran-Skin test, Fisher-ADF test and Fisher-PP test. The test results as shown in Table 5.

As can be seen from Table 5, the 6 selected variables (purchasing power parity exchange rates, economic growth, the nominal exchange rate, foreign direct investment, net trade condition index, final consumer spending in the annual growth rate) have no unit root whether with trends or not, we can estimate panel model directly.

\subsubsection{Estimation and Analysis of Panel Model}

Since the sample $N=62$ is larger than period $T=14$, the generalized least squares method (4) is used to correct the entire model fitting is good. Because of the sample countries is more, this article only listed the typical

\begin{tabular}{|c|c|c|c|c|c|c|c|c|c|}
\hline \multirow[b]{2}{*}{ Variables } & \multicolumn{2}{|c|}{ ILC statistic } & \multirow{2}{*}{$\begin{array}{c}\begin{array}{c}\text { Breitung } \\
\text { statistic }\end{array} \\
\text { Individual } \\
\text { trend and } \\
\text { int }\end{array}$} & \multicolumn{2}{|r|}{$\begin{array}{c}\text { IPS } \\
\text { statistic }\end{array}$} & \multicolumn{2}{|c|}{ Fisher-ADF statistic } & \multicolumn{2}{|c|}{ Fisher-PP statistic } \\
\hline & $\begin{array}{l}\text { Individual } \\
\text { inter }\end{array}$ & $\begin{array}{l}\text { Individual } \\
\text { trend and } \\
\text { int }\end{array}$ & & $\begin{array}{l}\text { Individual } \\
\text { inter }\end{array}$ & $\begin{array}{l}\text { Individual } \\
\text { trend and } \\
\text { int }\end{array}$ & $\begin{array}{l}\text { Individual } \\
\text { inter }\end{array}$ & $\begin{array}{l}\text { Individual } \\
\text { trend and } \\
\text { int }\end{array}$ & $\begin{array}{c}\text { Individual } \\
\text { inter }\end{array}$ & $\begin{array}{c}\text { Individual } \\
\text { trend and } \\
\text { int }\end{array}$ \\
\hline $\ln \left(P_{t} / P_{t-1}\right)$ & $\begin{array}{c}-21.12^{* * *} \\
(0.00)\end{array}$ & $\begin{array}{c}-21.55^{* * *} \\
(0.00)\end{array}$ & $\begin{array}{c}-7.24^{* * *} \\
(0.00)\end{array}$ & $\begin{array}{c}-15.64^{* * *} \\
(0.00)\end{array}$ & $\begin{array}{c}-12.21^{* * *} \\
(0.00)\end{array}$ & $\begin{array}{c}447.16^{* * *} \\
(0.00)\end{array}$ & $\begin{array}{c}348.66^{* * *} \\
(0.00)\end{array}$ & $\begin{array}{c}477.11^{* * *} \\
(0.00)\end{array}$ & $\begin{array}{c}411.02^{* * *} \\
(0.00)\end{array}$ \\
\hline $\ln \left(Y_{t} / Y_{t-1}\right)$ & $\begin{array}{c}-17.39^{* * * *} \\
(0.00)\end{array}$ & $\begin{array}{c}-17.78^{* * *} \\
(0.00)\end{array}$ & $\begin{array}{c}-7.7^{* * *} \\
(0.00)\end{array}$ & $\begin{array}{c}-12.43^{* * *} \\
(0.00)\end{array}$ & $\begin{array}{l}-7.8^{* * *} \\
(0.01)\end{array}$ & $\begin{array}{c}369.57^{* * *} \\
(0.00)\end{array}$ & $\begin{array}{c}261.4^{* * * *} \\
(0.01)\end{array}$ & $\begin{array}{c}426.42^{* * *} \\
(0.00)\end{array}$ & $\begin{array}{c}429.84^{* * *} \\
(0.00)\end{array}$ \\
\hline $\ln \left(E_{t} / E_{t-1}\right)$ & $\begin{array}{c}-20.49^{* * * *} \\
(0.00)\end{array}$ & $\begin{array}{c}-17.8^{* * *} \\
(0.00)\end{array}$ & $\begin{array}{c}-5.53^{* * *} \\
(0.00)\end{array}$ & $\begin{array}{c}-14.38^{* * *} \\
(0.02)\end{array}$ & $\begin{array}{c}-8.91^{* * *} \\
(0.00)\end{array}$ & $\begin{array}{c}404.58^{* * *} \\
(0.03)\end{array}$ & $\begin{array}{c}290.32^{* * * *} \\
(0.00)\end{array}$ & $\begin{array}{c}391.55^{* * *} \\
(0.02)\end{array}$ & $\begin{array}{c}465.77^{* * *} \\
(0.00)\end{array}$ \\
\hline FDI & $\begin{array}{c}-10.64^{* * *} \\
(0.00)\end{array}$ & $\begin{array}{c}-14.2^{* * *} \\
(0.00)\end{array}$ & $\begin{array}{c}-5.15^{* * *} \\
(0.00)\end{array}$ & $\begin{array}{c}-8.00^{* * *} \\
(0.00)\end{array}$ & $\begin{array}{c}-7.06^{* * *} \\
(0.00)\end{array}$ & $\begin{array}{c}278.71^{* * *} \\
(0.00)\end{array}$ & $\begin{array}{c}256.41^{* * *} \\
(0.00)\end{array}$ & $\begin{array}{c}302.46^{* * *} \\
(0.04)\end{array}$ & $\begin{array}{c}296.23^{* * *} \\
(0.00)\end{array}$ \\
\hline$E I$ & $\begin{array}{c}-10.26^{* * *} \\
(0.00)\end{array}$ & $\begin{array}{c}-15.41^{* * *} \\
(0.00)\end{array}$ & $\begin{array}{c}-3.96^{* * *} \\
(0.01)\end{array}$ & $\begin{array}{c}-1.08^{* * *} \\
(0.00)\end{array}$ & $\begin{array}{c}-4.36^{* * *} \\
(0.00)\end{array}$ & $\begin{array}{c}125.31^{* * *} \\
(0.00)\end{array}$ & $\begin{array}{c}179.19^{* * *} \\
(0.00)\end{array}$ & $\begin{array}{c}138.65^{* * *} \\
(0.00)\end{array}$ & $\begin{array}{c}211.46^{* * *} \\
(0.00)\end{array}$ \\
\hline CS & $\begin{array}{c}-18.1^{* * *} \\
(0.00)\end{array}$ & $\begin{array}{c}-19.64^{* * *} \\
(0.00)\end{array}$ & $\begin{array}{c}-8.98^{* * *} \\
(0.00)\end{array}$ & $\begin{array}{c}-12.97^{* * *} \\
(0.00)\end{array}$ & $\begin{array}{c}-11.22^{* * *} \\
(0.00)\end{array}$ & $\begin{array}{c}398.62^{* * *} \\
(0.00)\end{array}$ & $\begin{array}{c}338.56^{* * * *} \\
(0.00)\end{array}$ & $\begin{array}{c}480.46^{* * *} \\
(0.00)\end{array}$ & $\begin{array}{c}502.26^{* * *} \\
(0.00)\end{array}$ \\
\hline
\end{tabular}

Table 5. Panel unit root test results.

Note: $P$-values are in parentheses. ${ }^{* * *}$ Indicate a rejection of the null hypothesis of no unit root at the $1 \%$ level of significance. Breitung only tests the situation of the trend.

${ }^{2}$ Two $\mathrm{F}$ test hypotheses for determining the model form $H_{1}: \beta_{1}=\beta_{2}=\cdots=\beta_{N}$ and $H_{2}: \alpha_{1}=\alpha_{2}=\cdots=\alpha_{N}, \beta_{1}=\beta_{2}=\cdots=\beta_{N}$. If accept $H_{2}$ then it is a constant parameter model. If reject $H_{2}$ and receive $H_{1}$, we should select the variable intercept model. If two hypotheses are rejected, we choose the variable parameter model. 
the variance of the residuals. Table 6 results show that the influence factors of the member of the cross section are significant. Adjusted $R^{2}$ is greater than $0.9, D W$ is about 2 , and $F$ is bigger, $P$ is equal to 0 , which shows that countries.

Overall, 1) no matter what level the economies are, The annual relative change rate of per capita income and exchange rate are the main factors to explain the purchasing power parity exchange rate, the following factors are Foreign direct investment and Net trade condition index, then the weakest is the final consumption expenditure growth rate. 2) In most economies, The changing direction of per capita income, exchange rate and foreign direct investment proportion is the same with purchasing power parity, the elastic coefficient of high income is lower than upper \& middle income economies; The per capita income increase will reduce the purchasing power parity in developing economies, however different improvement of Net trade condition play different impact on the purchasing power parity. But each type of economies presents different characteristics. As follows:

1) In low Income economies, The annual relative variation of exchange rate is slightly bigger than the per capita income on the role of the purchasing power parity exchange rate, shows that $\beta_{2 i}>\beta_{1 i}$. The elastic coefficient of exchange rate for the purchasing power parity is greater than 1 , further confirmed the existence of Balassa-Samuelson effect as time goes by, and in a developing economy purchasing power parity grows faster than the exchange rate. When the foreign direct investment proportion increases 1 unit, purchasing power parity exchange rates fell by $0.01 \%-0.02 \%$ relative to the previous year, so this shows that low income countries use foreign advanced technology and equipment and management experience can improve its productivity, furthermore improve the workers' wages of the whole country. But consumption demand is weak in poor countries, when the supply increases, the same goods or services prices may appear a decline trend, thus makes the Low Income economies residents enjoy cheap goods. Another possible explanation for the main purpose of investing in these poor countries is to help them develop in order to improve the international influence, which is meet the goal of improving the economic growth and price stability at the same time. The improvement of net trade condition index pull an up effect about $0.05 \%$ on the average price level. Generally speaking, the improvement of net trade condition index has three cases, that are import prices unchanged but export prices rise, import prices fell but export prices unchanged and the import and export price changes at the same time. According to the

Table 6. Panel model parameter estimation results.

\begin{tabular}{|c|c|c|c|c|c|c|c|}
\hline Income groups & Countries & $\alpha_{i}$ & $\beta_{1 i}$ & $\beta_{2 i}$ & $\beta_{3 i}$ & $\beta_{4 i}$ & $\beta_{5 i}$ \\
\hline \multirow{4}{*}{ Low income } & Benin & -0.0537 & $0.6801^{* * *}$ & $0.7014^{* * *}$ & $-0.0058^{* *}$ & $0.0531^{* *}$ & $0.0151^{* *}$ \\
\hline & Rwanda & -0.1211 & $1.0190^{* * *}$ & $1.4789^{* * *}$ & $-0.0235^{* * *}$ & $0.0424^{* *}$ & $-0.0023^{* *}$ \\
\hline & Uganda & 0.0511 & $1.0791^{* * *}$ & $1.2301^{* * *}$ & $-0.0117^{* * *}$ & $0.0375^{* *}$ & $-0.0061^{*}$ \\
\hline & Burkina faso & -0.0082 & $0.8512^{* * *}$ & $0.8913^{* * *}$ & $-0.0109^{* * *}$ & $0.0514^{* *}$ & $0.0102^{* *}$ \\
\hline \multirow{4}{*}{$\begin{array}{l}\text { Low\&middle } \\
\text { income }\end{array}$} & Bolivia & -0.0107 & $0.8618^{* * *}$ & $0.8536^{* * *}$ & $0.0439^{* *}$ & $0.0232^{* * *}$ & $-0.0102^{* *}$ \\
\hline & Indonesia & -0.0386 & $0.8851^{* *}$ & $0.8886^{* * *}$ & $0.0471^{*}$ & $0.0184^{* *}$ & $-0.0057^{*}$ \\
\hline & Philippines & 0.0665 & $0.3729^{* *}$ & $0.4595^{* * *}$ & $0.0529^{*}$ & $-0.0214^{*}$ & $-0.0418^{* *}$ \\
\hline & Vietnam & -0.4172 & $0.8702^{* * *}$ & $0.9052^{* * *}$ & $0.0446^{* *}$ & $0.0372^{* * *}$ & $-0.0198^{* *}$ \\
\hline \multirow{4}{*}{$\begin{array}{l}\text { Upper middle } \\
\text { income }\end{array}$} & Brazi & 0.0178 & $0.8018^{* * *}$ & $0.9003^{* * *}$ & $0.0190^{* * *}$ & $0.0053^{*}$ & $-0.0040^{* *}$ \\
\hline & China & 0.1121 & $0.6515^{* * *}$ & $0.5728^{* *}$ & $0.0184^{* * *}$ & $-0.0188^{*}$ & $-0.0012^{* *}$ \\
\hline & Malaysia & -0.3954 & $0.6885^{* * *}$ & $0.5760^{* * *}$ & $0.0166^{*}$ & $0.0041^{* *}$ & $-0.0027^{* *}$ \\
\hline & Turkey & -0.0501 & $0.8800^{* * *}$ & $0.9035^{* * *}$ & $0.0257^{* *}$ & $0.0012^{*}$ & $-0.0011^{* *}$ \\
\hline \multirow{4}{*}{ High Income } & Iceland & -0.1449 & $-0.598^{* * *}$ & $-0.4577^{* * *}$ & $0.0031^{* * *}$ & $0.0023^{* *}$ & $0.0001^{*}$ \\
\hline & Italy & -0.0575 & $0.1111^{* *}$ & $0.2120^{*}$ & $0.0113^{*}$ & $0.0070^{* *}$ & $0.0024^{*}$ \\
\hline & Japan & 0.0089 & $-0.3162^{* *}$ & $-0.2748^{*}$ & $0.0121^{* *}$ & $0.0044^{* *}$ & $0.0178^{* *}$ \\
\hline & Singapore & 0.1191 & $0.3340^{* *}$ & $0.6241^{* *}$ & $0.0013^{*}$ & $0.0111^{* *}$ & $0.0012^{*}$ \\
\hline \multicolumn{2}{|c|}{ Adjusted $\mathrm{R}^{2}=0.912$} & \multicolumn{2}{|c|}{$\mathrm{DW}=2.129$} & \multicolumn{2}{|c|}{ F-statistics $=25.212$} & \multicolumn{2}{|c|}{$\mathrm{P}$-value $=0.000$} \\
\hline
\end{tabular}

Note: ${ }^{* * * *}$ and ${ }^{*}$ indicate respectively a rejection of the null hypothesis of no unit root at the $1 \%, 5 \%$ and $10 \%$ level of significance. 
affect direction of net trade condition index on purchasing power parity exchange rate, you can speculate that the improvement of net trade condition index is caused by import prices unchanged but export prices rise or the import and export price all rise, which also reflects that the improvement of foreign trade environment pull up the price level in low income economies, this is consistent with the fact that price level generally rise in low income economies because of the influence of international trade. Finally, the increase of the final consumption expenditure proportion will eventually improve the purchasing power parity, because of poor countries cannot meet the demand of the people's daily life, thus foreign supplies are needed, and usually the price of imported consumer goods are higher than domestic production.

2) The contribution degree of variation of per capita income and exchange rate to purchasing power parity exchange rate in low \& middle income economies is slightly lower than that in low income economies. For just get rid of the poverty, its per capita GDP growth is more dependent on infrastructure investment, and these investment services mainly service the domestic sector, but there is no direct improvements in productivity of the international department, so the corresponding growth of price level does not appear (Wang, L., et al., 2013) [18]. Foreign direct investment has a positive impact on purchasing power parity exchange rate, and specific performance as follows: when the foreign direct investment proportion increase 1 unit, purchasing power parity exchange rates rise $0.01 \%$ to $0.05 \%$ relative to the previous year. Many countries engage in processing trade activities as a form of using foreign capital, then manufactured goods will be shipped to the rest of the world, they are not only get part of the processing fee, but also increase the international trade department production efficiency greatly, in turn a country's overall price level is improved. Finally, the increase of the final consumption expenditure proportion does not improve the overall price level, this is due to the government departments in low \& middle income economies tend to offer certain subsidy to residents' consumer goods, which lead to make real price well below market price, thus the increase of the final consumption expenditure proportion may pull down prices across the economy.

3) In upper middle income economies, the contribution degree of China and Malaysia on the variation of purchasing power parity exchange rate is lowest. The reasons for this phenomenon may be China's investment efficiency is not high ${ }^{3}$. That is to say, the growth of per capita GDP in the data is not bring the country's productivity compared with other countries. This kind of speculation is matched with the fact that China has presented a low efficiency of investment for a long time. However, Malaysia is facing an income system imbalance and the gap between rich and poor accompanying with the "middle-income trap" in the mid-1990s, that makes GDP growth results not be shared by the national, but the production capacity increases, and that may be a factor leading to limiting the price level relative to other countries rise. In the contribution degree of variation of exchange rate to the national average price, elastic coefficient of exchange rate in Brazil and Turkey are the largest, the reason is Brazil as one of international commodity exporters hold international commodity pricing power, so it can control the price to a certain degree to keep its profitability remains the same under the background of currency depreciation (the price expressed in local currency remains the same). Based on this consideration, it is not difficult to understand the phenomenon that the variation of the exchange rate has bigger influence on the national average price; Turkey's elastic coefficient is larger due to its high trade dependence and economic freedom ${ }^{4}$, namely the more close with the world economic and the more flexible price mechanism, the purchasing power parity (PPP) is more sensitive to exchange rate changes. In addition, foreign direct investment proportion would increase domestic average level. The reason is the same as low \& middle income economies. The improvement of net trade condition index impacts on the economic income level price which presents a differentiation phenomenon. The improvement of net trade condition index makes purchasing power parity fall in China, Mauritius, and Peru, the reason is the development of economy and adjustment the trade policy (such as more preferential tariffs, etc.), that makes import price fall faster than export price under the background of international economy remains weak. Thus, this kind of foreign trade ascension will lead to decline in purchasing power parity. The degree of the increase of the final consumption expenditure proportion impacts on the price level was not significant, but the variable is significant in other economies. Why does this kind of result appear and what the results mean? There is still the necessity of further research.

\footnotetext{
${ }^{3}$ Two typical examples: First, the Chinese government took out 4 trillion in 2008 to rescue, although play a certain role for China’s economic recovery, but this kind of "Go" way of investment does not improve the actual production efficiency for economies; The second, phenomenon of excess production capacity of oversupply as a result of China's excessive investment greatly reduce the marginal benefit of investment.

${ }^{4}$ From 2000 to 2013, Turkey’s foreign dependency ratio is as high as 50\%, and economic freedom is about 7.
} 
4) High income economies present the obvious characteristics that the elastic coefficient of the variation of the per capita income is small and the annual variation of GDP per capita of some economies do not increase to the purchasing power parity, on the contrary make the purchasing power parity lower; It is worth noting that influence coefficient of exchange rate presents the characteristics basically similar to the former. Such as income increases and exchange rate depreciation make purchasing power parity of the eight economies decline, included Iceland, Japan, Chile, etc. This kind of phenomenon can be interpreted as when per capita income reaches a certain threshold, further improvement of the income level will lead to domestic average price level drop. The reason may be: As income increases, the productivity of these countries present the downward trend relative to the rest of the world. Namely, the poor countries show the production efficiency increase significantly through introducing the equipment, technology and capital of the advanced countries. While the production efficiency of the advanced countries is at a slow pace of ascension due to undertake the task of innovation. In addition, exchange rate depreciation often leads to import prices level expressed in local currency ascend and export prices expressed in foreign currency fall. Meanwhile, advanced countries usually import raw materials of primary products, and these products are often account for small proportion of GDP, but export high-tech products accounted for big proportion of GDP. Thus, export products price has a greater impact on average home prices. So exchange rate depreciation of advanced countries will lead to purchasing power parity decline. The elastic coefficient of foreign investment proportion to purchasing power parity is smaller than in low income economies, the research results is consistent with Zhihua Liu (2009): foreign investment helps to global price convergence. Unlike the low income economies, the variation of the final consumption expenditure proportion to purchasing power parity is in the same direction.

\subsection{Robustness Test}

In order to further test the reliability of the regression results, this part selected the main output data of the two rounds (2005 and 2011) of the international comparison other indicators to establishment a pure cross section equation. The specific model setting is:

$$
\ln \left(P_{i 11} / P_{i 05}\right)=\alpha+\beta_{1} \ln \left(Y_{i 11} / Y_{i 05}\right)+\beta_{2} \ln \left(E_{i 11} / E_{i 05}\right)+\beta_{3} F D I_{i}^{*}+\beta_{4 i} E I_{i}^{*}+\beta_{5} C S_{i}^{*}+\varepsilon_{i}
$$

FDI $^{*} \quad$ EI $^{*}$ and $C S^{*}$ are the average value of 2005 and 2011 year, other variables' meanings are the same as formula (4). The results are shown in Table 7.

We adopt the stepwise regression method, and first use $\ln \left(P_{t} / P_{t-1}\right)$ as the dependent variable, at the same time $\ln \left(Y_{i 11} / Y_{i 05}\right)$ as the independent variable, then the other independent variables are added to the model step by step. The results are shown in Table 7. Among the 5 model, the estimation results are more consistent, the sign of the independent variable doesn't changed and is significant at 5\%. We can draw such a conclusion that with the increase of the explanatory variables, the model interpretation ability improve gradually. Statistics show

Table 7. The regression analysis results.

\begin{tabular}{|c|c|c|c|c|c|}
\hline Variables & (1) & (2) & (3) & (4) & (5) \\
\hline Constant term & $\begin{array}{c}-0.0975^{* * *} \\
(-2.982)\end{array}$ & $\begin{array}{l}-0.0988^{* * *} \\
(-3.0124)\end{array}$ & $\begin{array}{c}-0.1042^{* * *} \\
(-3.186)\end{array}$ & $\begin{array}{c}-0.1438^{* * *} \\
(-3.565)\end{array}$ & $\begin{array}{c}-0.1644^{* * *+} \\
(-3.747)\end{array}$ \\
\hline $\ln \left(Y_{i 11} / Y_{i 05}\right)$ & $\begin{array}{l}0.4124^{* * *} \\
(-9.9366)\end{array}$ & $\begin{array}{l}0.4751^{* * *} \\
(20.3240)\end{array}$ & $\begin{array}{l}0.5084^{* * *} \\
(17.7450)\end{array}$ & $\begin{array}{l}0.4965^{* * *} \\
(16.6263)\end{array}$ & $\begin{array}{l}0.6015^{* * *} \\
(13.9137)\end{array}$ \\
\hline $\ln \left(E_{i 11} / E_{i 05}\right)$ & & $\begin{array}{l}0.8318^{* * *} \\
(11.9397)\end{array}$ & $\begin{array}{l}0.8420^{* * *} \\
(12.2587)\end{array}$ & $\begin{array}{l}0.8385^{* * *} \\
(12.2767)\end{array}$ & $\begin{array}{l}0.8698^{* * *} \\
(14.1307)\end{array}$ \\
\hline$F D I^{*}$ & & & $\begin{array}{c}0.0047^{*} \\
(-1.9303)\end{array}$ & $\begin{array}{c}0.0053^{* *} \\
(-2.1490)\end{array}$ & $\begin{array}{c}0.0069^{* *} \\
(-2.3953)\end{array}$ \\
\hline$E I^{*}$ & & & & & $\begin{array}{c}0.0058^{*} \\
(0.0623)\end{array}$ \\
\hline$C S^{*}$ & & & & $\begin{array}{c}-0.0098^{* * * *} \\
(2.3216)\end{array}$ & $\begin{array}{c}-0.0021^{* * *+} \\
(2.8074)\end{array}$ \\
\hline$R^{2}$ & 0.3584 & 0.7099 & 0.7613 & 0.8265 & 0.8666 \\
\hline$D W$ & 2.0573 & 2.0141 & 2.0605 & 2.0511 & 2.0304 \\
\hline
\end{tabular}

Note: t-statistics are in parentheses. ${ }^{* * * * *}$ and ${ }^{*}$ indicate respectively a rejection of the null hypothesis at the $1 \%, 5 \%$ and $10 \%$ level of significance. 
that model 5 is the best fitting results and its independent variable are same as formula (4). From the point of estimated coefficients, $\ln \left(Y_{i 11} / Y_{i 05}\right)$ and $\ln \left(E_{i 11} / E_{i 05}\right)$ have a little different (0.6015 and 0.8698 respectively), and both are significant at the level of $1 \%$, which is similar to the panel estimates. On the whole, the per capita income and nominal exchange rate have a positive correlation with the purchasing power parity exchange rate, that is, when the two the increase $1 \%$,the purchasing power parity exchange rate corresponding increase $0.60 \%$ and $0.87 \%$; The estimation coefficient sign of $F D I^{*} E I^{*}$ and $C S^{*}$ have little different, but its absolute value is less than 0.007 . This shows that the annual growth rate of foreign direct investment, net trade condition and final consumption expenditure have little effect on the change of the purchasing power parity exchange rate. Moreover, with the increase of income level, the coefficient of the variable has changed, so offset may be one of the reasons causing the above three variables estimation coefficient smaller. To sum up, the estimation results of the panel model (4) are robust.

\section{Conclusions}

Using the data of 62 countries (regions) in 2000-2013, this paper establishes a variable coefficient fixed effect panel model to study the changes in domestic and international macroeconomic factors on the fluctuation of purchasing power parity (PPP). Statistics show that domestic economic growth and exchange rate changes are two main factors to explain purchasing power parity (PPP) variation. Foreign investment and trade condition have little effect on the ups and downs of the purchasing power parity (PPP), and consumer spending has an effect in high-income economies and low-income economies in a different direction. Statistical characteristics of PPP exchange rates show that purchasing power parity (PPP) annual change in low and middle income economies is positive, and annual change in part of the high-income economies is negative. As the global economic integration accelerates, the low and middle income economies' purchasing power parity (PPP) shows a rising trend, meanwhile, high-income economies shows a decline trend, which indicts the global price level tends to convergence.

Further analysis shows that: with the increase of income level, the annual change of per capita income and exchange rate has different characteristics in contribution to the purchasing power parity exchange rate. The purchasing power parity is influenced greatly by the per capita income and exchange rate changes in low income economics. In middle-income countries (including low and middle income and high income), the contribution of per capita income and exchange rate changes are lower, and the two elasticity coefficient are equivalent; While the contribution of per capita income and exchange rate changes to high income countries become even lower, especially when relative price level has more than 1 , so the income has played a negative regulatory role, which makes the PPP and the nominal exchange rate tends to be consistent. The increase of the proportion of foreign investment can bring good quality and inexpensive goods for low income economies, and improve the living standards of residents. This is the reason why the economy has introduced foreign capital, and the elasticity coefficient of high income economy is less than that of medium income. That basically confirms the conclusion foreign investment can help to ease the price level of the countries. And the improvement of conditions of foreign trade is the cause of the rising purchasing power parity (PPP) in the whole world. Consumer spending increase will improve purchasing power parity (PPP) of the developed economies, but it will lead to a decline in low-income economies purchasing power parity (PPP). The main reason is the government in low and middle income economy often offer certain price subsidies to consumer goods, which make its price deviate from the market price level, so when this part expenditure increases the economy's price level tends to decline. This is account that combining macro economies variables can provide some useful information for benchmark year PPP estimates, especially with the improvement of income level, each variable changes have different effect on purchasing power parity (PPP). But should pay attention to we can't use a unified model to estimate the change of the purchasing power parity (PPP).

We can foresee that under the background of China's economic structure's continuous optimization and upgrading. Meanwhile, elements and investment drive convert into innovation drive in economic development, so per capita income level is still huge room to improve. In addition, China exists huge trade surplus and the appreciation of RMB nominal exchange rate is under large pressure for a long time. Comparing the elastic coefficient of nominal exchange rate and per capita income, it is not difficult to conclude that China's purchasing power parity (PPP) will continue to be a growth trend in the future.

\section{Acknowledgements}

Hua Niu, Xiaoyuan Chu, and Yanxin Ma thank the Project of National Social Science Foundation under Grant 
No. 13AZD086.

\section{References}

[1] Deaton, A. and Heston, A. (2008) Understanding PPPs and PPP-Based National Account. NBER Working Paper 14499. http://www.nber.org/papers/w14499

[2] Yu, F.D. (2015) The Methodology, the Results and the Limitations of 2011 ICP Round by the World Bank. Statistical Research, 1, 11-19.

[3] Yu, F.D. (2008) Some Issues on the International Comparison Program by World Bank in 2005. Statistical Research, 6, 3-10.

[4] Deaton, A. and Aten, B. (2014) Trying to Understand the PPPs in ICP2011:Why Are the Results so Different? NBER Working Paper 20244. http://www.nber.org/paper/w20244

[5] Lawrence, C. and Kharas, H. (2014) What Do New Price Data Mean for the Goal of Ending Extreme Poverty? Brookings. http://www.brookings.edu/blogs/up-front/posts/2014/05/05

[6] Yu, F.D. (2013) Reviewing the Non-Benchmark Estimates for PPP. Statistical Research, 3, 26-29.

[7] Balassa, B. (1964) The Purchasing Power Parity Doctrine: A Reappraisal. The Journal of Political Economic, 6, 584595. http://dx.doi.org/10.1086/258965

[8] Cheung, Y.-W., Chinn, M.D. and Fuji, E. (2007) The Overvaluation of Renminbi Undervaluation. Journal of International Money and Finance, 5, 762-785. http://dx.doi.org/10.1016/j.jimonfin.2007.04.005

[9] Froot, K.A. and Rogoff, K. (1994) Perspectives on PPP and Long-Run Real Exchange Rates. Harvard and Princeton Universities, Mimeo.

[10] Robert, C., Feenstra, J. and Kendall, D. (1994) Pass through of Exchange Rates and Purchasing Power Parity. NBRE Working Paper No. 4842. http://www.nber.org/papers/w4842

[11] Bhagwati, J.N. (1984) Why Are Services Cheaper in Poor Countries? The Economic Journal, 94, 279-286. http://dx.doi.org/10.2307/2232350

[12] Ravallion, M. (2014) An Exploration of the International Comparison Program's New Global Economic Landscape. NBER Working Paper No. 20338. http://www.nber.org/papers/w20338

[13] Clague, C.K. (1985) A Model of Real National Price Levels. Southern Economic Journal, 51, 998-1017. http://dx.doi.org/10.2307/1058373

[14] Lipsey, R.E. (2002) Home and Host Country Effects of FDI. Working Paper 9293. http://www.nber.org/papers/w9293

[15] World Bank (2005) Global Purchasing Power Parities and Real Expenditures. 2005 International Comparison Program, World Bank, Washington DC.

[16] Liu, Y.F., He, J.X., Liu, X.L., Li, H. and Man, J.Y. (2007) An Empirical Analysis on Differences of Two Methods for Measuring GDP. Economic Research Journal, 7, 51-63.

[17] Wang, L. and Fan, C. (2013) The Research on Purchasing Power Parity Deviates from Exchange Rate. The Journal of Quantitative and Technical Economics, 11, 125-142.

[18] Liu, Z.H., Wu, S.Q. and Ge, Z. (2009) Research on the Relation between FDI and International Trade. Mathematics in economics, 6, 59-64.

[19] Sun, W.Z. (2009) The Mechanism Analysis of the Effect of Price Changes in Terms of Trade on Economic Growth. Academic Communication, 10, 66-68.

[20] Pan, S.M. and Lai, M.Y. (2010) Research on the FDI and RMB Real Exchange Rate Fluctuation. Statistics and Decision, 9, 120-121.

[21] Ravallion, A. (2010) Price Levels and Economic Growth: Making Sense of the PPP Changes between ICP Rounds. World Bank Policy Research Working Paper 5229. http://dx.doi.org/10.1596/1813-9450-5229

[22] Chen, M.G. and Yin, D.C. (2015) The Analysis of "Purchasing Power Parity (PPP) and China Is the First in the World" from the Perspective of ICP. Journal of China National School of Administration, 4, 108-111.

[23] Gao, T.M. (2009) Econometric Analysis Method and Modeling. Tsinghua University Press, Beijing. 